\title{
Do bank credit rejection and financial education affect financial self-confidence?
}

\begin{abstract}
Purpose

This paper empirically examines the determinants of owner manager financial selfconfidence. In particular, it estimates the effect of bank credit rejection and financial education on the financial self-confidence of business owners.

\section{Design/methodology/approach}

This article uses data from 2004 and 2008 surveys of 2500 UK small and medium-sized enterprises (SMEs). An ordered probit estimation is used to measure and assess the effect of bank credit rejection and financial education variables on financial self-confidence for the two periods. We also explore potential differences in self-confidence between males and females.
\end{abstract}

\section{Findings}

The results show that outright bank credit rejection reduces financial self-confidence among owner managers whereas partial bank credit rejection is found to help boost confidence prior to the financial crisis. There is strong evidence that financial education increases financial self-confidence. Finally, we find no association between gender and reported self-confidence in finance.

\section{Research limitations/implications}

Entrepreneurs and potential entrepreneurs are encouraged to explore financial literacy and knowledge with a view to increasing their financial self-confidence. This will help SMEs to deal with the banks or other finance providers more efficiently. In addition, better application procedures and information on lending criteria may help SMEs to minimise the probability of bank credit rejection. So the current study has implications for professional bodies as well. The study, however, is restricted to sole proprietor and partnership SMEs and in the UK context only.

\section{Practical implications}

Financial self-confidence has a progressive effect on entrepreneurship and entrepreneurial venture growth. The financial self-confidence of owner managers can support their entrepreneurial capability in starting and operating one or more businesses. As entrepreneurs successfully start and operate their own businesses, they are contributing to economic development through job creation, employment and tax contribution.

\section{Originality/value}

This paper makes an original contribution in highlighting the usefulness of financial education in boosting financial self-confidence among entrepreneurs and potential entrepreneurs. It is also found that the experience of bank credit rejection reduces entrepreneurs' financial self-confidence.

Keywords: Self-confidence; Access to finance; SMEs; Gender; Financial education; Bank credit rejection 


\section{Introduction}

It is universally acknowledged that entrepreneurship is a high-risk endeavour that has a low probability of success (Shepherd et al., 2010). Since entrepreneurship is faced with market uncertainties and macroeconomic instabilities, an entrepreneur's self-confidence can act as an important antecedent to start up a new firm and sustain growth (Busenitz and Barney, 1997 Forbes, 2005; Parker, 2006; Koellinger et al., 2007; Hayward et al., 2010; Ucbasaran et al., 2015). Thus, self-confidence may be viewed as a positive phenomenon and entrepreneurs who exhibit such reap the rewards in terms of enhancing firm performances (Robinson, 2001; Disney and Gathergood, 2013). Self-confidence in the context of entrepreneurship is a multidimensional concept inclusive of emotional, cognitive, social and financial resiliencies (Zhao et al., 2005; Wilson et al., 2007; McGee et al., 2009), and it is this trait that separates the entrepreneurs from the non-entrepreneurs (Minniti et al., 2004). For example, Asoni (2011) finds that self-confidence positively influences the entry into entrepreneurship.

Some research, however, finds that individuals have a tendency to process information about their ability in a biased manner (Möbius et al., 2011). For example, Rae and Carswell (2001) find that entrepreneurs may have biased tendencies in their abilities to start and run their own businesses, thus they may be overly self-confident. An unduly biased perception of ones' abilities, knowledge and future prospects are identified in the literature, as features that could result in overconfidence (Barber and Odean, 2001). In other words, overconfidence is simply a biased state of self-confidence or an excessive aspect of selfconfidence (Moore and Healy, 2008). ${ }^{1}$ In retrospect, one may argue that overconfidence can provide a value to a firm (see Galasso and Simcoe, 2010). However, overconfidence increases the likelihood of errors within the decision making process and this can have negative consequences for the growth prospects of the firm (see Malmandier and Tate, 2008; Trevelyan, 2008, Yazdipour and Constand, 2010; Pirinsky, 2013).

Since perceived self-confidence has been found to be associated with entrepreneurial behaviour and outcomes, it is important to understand how it is formed. In this paper, we are

\footnotetext{
${ }^{1}$ Additionally, Barber and Odean- (2001) and Moore and Healy (2008) find that male investors exhibit higher financial overconfidence when compared to female investors. Thus, there is a potential gender dimension to overconfidence. Huang and Kisgen (2013), for example, find that the male executives exhibit higher levels of overconfidence in most corporate financial and investment decision makings. On the other hand, the lack of or low self-confidence is not an encouraging factor for firm growth and survival (e.g. Bowen and Hisrich, 1986; Moore and Healy, 2008).
} 
interested in SME (small and medium sized enterprise) owner's self-confidence in finance. ${ }^{2}$ SMEs have faced financial constraints and cash flow problems in the aftermath of the financial crisis of 2007, because lenders have become more risk averse (Fraser, 2008; Cornett et al., 2011; Smallbone et al., 2012; Saridakis et al., 2013; Fraser et al., 2015; McGuinness and Hogan, 2016). At the same time, since the recent recession, there have been increases in the credit rejection rates by financial institutions and the percentage of discouraged borrowers, i.e. borrowers who do not apply for credit because they feel that they will be rejected, (see Fraser, 2008; Abildgren et al., 2013; Cole and Sokolyk, 2016). We argue that entrepreneurs who have been rejected for bank funding may have lower self-confidence in finance than those who have been accepted for credit which in turn can influence firm performance and survival prospects.

Hence, the paper primarily seeks to shed light on the impact of bank credit rejection on the financial self-confidence of business owners in times of booms i.e. pre-financial crisis and busts which occur during the financial crisis. ${ }^{3}$ This latter distinction somehow allows us to capture the potential effect of the recent financial crisis. In addition to the above contribution, this paper further examines the role of financial education on bank rejection. We argue that financial education can develop financial capabilities and learning about financial matters which together may enhance financial self-confidence (see Disney and Gathergood, 2013). Finally, it is also important to understand the gender dimension as it pertains to self-confidence in finance. For example, the existing research shows that while there is a tendency for males to exhibit financial overconfidence (e.g. Barber and Odean, 2001; Moore and Healy, 2008) it is not the same for females who tend to exert low financial self-confidence (e.g. Estes and Hosseini, 1988; Kirkwood, 2009). Hence, our study also contributes to the gender micro finance literature.

The remainder of this paper is organized as follows. After the introduction which is presented in section 1, section 2 provides the background, reviews the literature and develops the hypotheses to be tested. Section 3 describes the data source and sample analysis for this investigation. Section 4 outlines the empirical method that this study employs. Section 5 presents our results and analyses. Section 6 describes our findings and finally we conclude

\footnotetext{
${ }^{2}$ This study recognizes that self-confidence and self-efficacy are two terms that are often used interchangeably. Yet they are not the same. Bandura (1994) suggests that self-confidence is a positive state that enhances and promotes self-efficacy (see also Bandura 1982; Bass, 1990).

${ }^{3}$ Here we use the term "self-confidence" to comply with the terminology used by Fraser (2004).
} 
with section 7 which provides a conclusion with a summary of the research findings as well as directions for further research and policy implications.

\section{Background and hypotheses development}

\section{Bank rejection and self-confidence in finance}

It is acknowledged in the literature that financing is necessary for entrepreneurial start-up, growth and survival, furthermore, such financing is typically sourced via banks (Fraser, 2008; Saridakis et al., 2008; BIS, 2012; ECB Monthly Bulletin, 2014; Scottish Government, 2014). A characteristic feature of the recent financial crisis was the fragmentation of the financial markets. As a consequence, the traditional monetary policy transmission channels were disrupted, which led to greater financial constraints being imposed on firms, especially SMEs, in need of external financing. So there was the creation of a supply side "funding gap", more specifically, a "supply side funding shock" (Berg and Kirschenmann, 2012; Deyoung, et al., 2012; Carbó-Valverde et al., 2013; Kremp and Sevestre, 2013; Lee et al., 2015) because liquidity management activities of the banking system resulted in reductions in business credit lending (Ivashina and Scharfstein, 2010; Cornett et al., 2011; Popov and Udell, 2012).

Rae and Carswell, (2001) show that the self-confidence of the entrepreneurs with regards to their entrepreneurial learning actually enhance their self-beliefs in their capabilities that they can make their business ventures viable. Indeed, it is difficult to establish an entrepreneurial venture in the absence of personal self-confidence. Entrepreneurial selfconfidence is an emotionally loaded multidimensional concept inclusive of financial resilience: “... entrepreneurs' ability to obtain capital on subsequent ventures as a result of their decisions and actions on their focal ventures" (Hayward et al., 2010: 571). Financial resilience can therefore be viewed as financial self-confidence. Financial resilience also plays a significant role in the emergence of the serial entrepreneur who uses the positive emotions of prior successes to go into other ventures. Fredrickson's broaden and build theory of positive emotions (1998), implies that an increase in financial self-confidence positively influences the other three dimensions of entrepreneur self-confidence namely: the cognitive, social, and emotional resilience. Altogether, this increases the likelihood of serial entrepreneurship. On the other hand, negative emotions which can result from failed entrepreneurial ventures have the opposite effect.

Entrepreneurs begin their entrepreneurial career with a priori self-confidence in accessing finance. As entrepreneurs begin to apply for funding they observe their rejection 
rates and these result in the experiences having an effect on their self-confidence. Precisely, if an entrepreneur is rejected for funding, his or her self-confidence is expected to decrease and vice versa. Even more, some entrepreneurs who are rejected may never re-apply again for funding and become discouraged borrowers. Cowling et al. (2016) find that $55.6 \%$ of discouraged borrowers would have been successful later had they reapplied for loans. While Cole and Sokolyk, (2016) state that as much as one third of the discouraged borrowers could have been successful if they had reapplied for loans. The SMEs of such discouraged borrowers have weaker performances in terms of solvencies, profits, liquidities and debt profiles (Abildgren et al., 2013). Hence, their financial self-confidence will be negatively impacted in response to all this.

Given the above-stated factors this study, therefore, proposes the following hypothesis:

H1: Bank finance rejection reduces business owners' self-confidence in finance.

\section{Financial education and self-confidence in finance}

It can be argued that higher levels of financial education which is an entrepreneurial human capital ought to facilitate the making of better financial decisions. ${ }^{4}$ Additionally, the operationalizing of financial management practices that optimize entrepreneurial performances will be more efficient. Thus, greater levels of financial education should be a positive predictor of self-confidence and serial entrepreneurship as the other three dimensions of entrepreneurial self-confidence will be positively enhanced simultaneously.

Amongst many other individual characteristics, innovations in small firms depend on the education and self-confidence of the owner manager (Heunks, 1998). Persons who are less educated are unlikely to exhibit financial literacy (Disney and Gathergood, 2013) and consequently, they may have less self-confidence in finance. Disney and Gathergood, (2013) employ a recent UK household survey and find that people with lower levels of financial literacy are more likely to show lack of confidence and confusion in financial matters. They also show that financial literacy plays a major role in enabling financial self-confidence, hence, financial self-confidence has a positive association with good financial educational accomplishments and capabilities. Furthermore, financial education is part of entrepreneurial

\footnotetext{
${ }^{4}$ Furthermore, we can say that entrepreneurs with higher levels of education are less likely to be subjected to rejections of bank financing (see Fraser, 2004). In particular, researchers such as Cassar, (2004), Blumberg (2007) and del-Palacio et al. (2010) find that such owners experience fewer difficulties in accessing external financing.
} 
education which has a positive effect on human capital (Volery et al., 2013). If the firm owner lacks financial knowledge, however, he or she may engage in financial counselling that can support the entrepreneur in making better financial decisions which can improve performance (Drexler et al., 2013).

Research shows that entrepreneurs who possess greater amounts of education in the business environment as part of their human capital make better business decisions and this manifests in better firm performances (Blundell et al., 1999; Dakhli and De Clercq, 2004; Colombo and Grilli, 2005; Dickson et al., 2008; Karlan and Valdivia, 2010; Crook et al., 2011; Unger et al., 2011; Ganotakis, 2012; Block et al., 2013). To this end, many countries are supportive of financial literacy and financial education programs for their people in order to spur economic growth (Fernandes et al., 2014). This shows that the benefits of financial education may be far-reaching as they enable better credit applications and develop the ability to identify market opportunities. Furthermore, they may enable one to possess a clearer understanding of the terms and conditions which are associated with bank credits. The OECD suggests that financial education reduces financial illiteracy in the society (OECD, 2006). Amatucci and Crawley (2011) find in their study of 51 women entrepreneurs that financial education facilitates access to whatever necessary capital is required for start-ups, day to day operations and/or investments.

Given all this, we propose our second hypothesis:

H2: Entrepreneurs with greater financial education are more likely to have greater financial self-confidence.

Gender and self-confidence in finance: is there a difference?

"The greatest deterrent to women entrepreneurs is that they are women" (Revathi and Krishnan, 2012: 79) as they are typically faced with a gender biased financial constraint (Meenakshi and Mahapatra, 2015). This discriminatory attitude exists, notwithstanding the fact that females, when compared to males, are more likely to repay their loans (Gurnani, 2014). More precisely, gender, and not their risk averseness, is probably the most significant barrier that limits the number of female start-ups (Caleb et al., 2012). ${ }^{5}$ Hence, it is possible that gender biases can erode their financial self-confidence and even more so when the woman is financially educated.

\footnotetext{
${ }^{5}$ However, it must be noted that during the financial crisis the risk averse characteristic of females actually enabled them to obtain a greater proportion of their desired financing, when compared to males (Cosh et al., 2009).
} 
In self-employment choices, a recent study argues against the traditional alignment of social factors to female and economic factors to their male counterpart (Saridakis et al., 2014). Although the research explored social and economic factors in male and female selfemployment, it used UK time-series data. Hence, there may be issues of cultural irrelevance to other countries. In developing countries, environmental and cultural factors can lead to targeted policy formulation to support certain groups such as female entrepreneurs (Cho and Honorati, 2013). A study into the perception and behaviour of male and female start-up entrepreneurs exposes the female deficiencies in the areas of finance and accounting in comparison to their male counterparts (Jones and Tullous, 2002). Although this study targeted a certain section of the United States community mostly, the findings are in line with the result from other researchers such as Bowen and Hisrich (1986) and Estes and Hosseini (1988). This shows that financial self-confidence can support entrepreneurs in starting and running their own businesses. SMEs are enablers of economic advancement in many countries through business start-up, job creation, and employment, courtesy of self-confident entrepreneurs who found the businesses (OECD, 2013; Robinson, 2001). Therefore, the sustainability of the economy depends on the self-confidence of entrepreneurs in engaging in new business formation. As financial service firms support local people in expanding economic activities, their income and assets are positively impacted and their self-confidence improves concurrently (Robinson, 2001). Tyszka et al. (2011) reveal that opportunity-driven entrepreneurs exhibit better self-confidence. Hence, as business opportunities increase, more entrepreneurs and potential entrepreneurs are motivated and their self-confidence improves.

Different risk factors contribute to different gender behaviours and unless the gender aspect of risk is adequately understood, it will be difficult to resolve risks and thus, inappropriate to make policy recommendation (Brindley, 2005). Gender stereotype plays a key role in business opportunity evaluations and favours males or females depending on the stereotypical information context (Gupta et al., 2014). The lower early business growth of female entrepreneurs contributes to their limited finance in entrepreneurship compared to their male counterparts (Alsos et al., 2006). Although Muravyev et al. (2009) identifies possible preferential treatment of males as opposed to females in access to finance, many studies (Bester, 1987; Voordeckers and Steijvers, 2006; Berger et al., 2011; Cotugno et al., 2012; Cowling et al., 2012;) suggest that lenders consider collateral, banking relationship and track record in their funding decisions. According to Bellucci et al. (2010), female entrepreneurs are more financially constrained and low confident female loan officers are less 
likely to approve loans for start-up businesses as compared to their male counterparts. This may suggest that female loan officers are more risk-averse.

A New Zealand study finds that women show lower self-confidence in their entrepreneurial abilities when compared to men and, as a result, the women entrepreneurs are constrained in growth and financial resources (Kirkwood, 2009). However, they find that self-confidence among women entrepreneurs grows with increases in their entrepreneurial experience. According to Estes and Hosseini (1988), women show lower confidence in investment-related tasks when compared to men. In another study, women are unable to determine their entrepreneurial career prospect as they feel a lack of confidence in financial matters (Bowen and Hisrich, 1986). Meanwhile, Wijewardena et al. (2008) find that the owner manager mentality directly impacts the financial performance of their organisations. As women are susceptible to low self-confidence, it shows that their level of mentality can have a negative effect on the performance of their firms. Thus, finance is a key resource in any business and access to finance becomes more elusive in the absence of self-confidence in financial matters that are relevant to the start-up and smooth operation of the business. Marlino and Wilson, (2003) find that girls, when compared to boys, report lower confidence levels in financial studies.

Based on the above literature, this study, therefore, proposes the following hypothesis:

H3: Male business owners have higher levels of self-confidence in finance than female business owners.

\section{Data}

The data for analysis in this study comes from the surveys of 2,500 UK SMEs during 2004 and 2008 (A full discussion of the data and sampling method are given in Fraser 2004 and 2008). The aims of the surveys were: a) to provide a benchmark SME finance database made up of the availability and types of finance for SMEs in the UK, b) to collect information on the relationship between SMEs and their providers of finance, and c) to provide a general purpose database that will support quantitative research on business finance in the UK and be comparable with other countries. Both datasets are representative of the SMEs who have up to 250 employees in the UK.

As the surveys were performed in two parts, one in 2004 and another in 2008, there are two separate cross-sectional datasets. The 2004 dataset provides a snapshot of the prefinancial crisis period and the 2008 dataset captures the financial crisis period. Therefore, the 
two datasets allowed for comparisons between the two periods. The surveys provide rich information about the characteristics of the business and its owner, self-confidence in finance and bank finance application outcomes. Although the surveys involved sole proprietor, partnership and limited companies, this study will concentrate on sole proprietor and partnership businesses because self-confidence data was not reported for limited companies.

Figure 1 provides a conceptual framework of self-confidence and credit finance application. It shows that while some business owners make applications for finance, others do not. However, among business owners who do not make applications for finance, it could either be that they may not need finance funding or that they may be discouraged. It can be assumed that prior to making application for finance, there is an initial level of selfconfidence. The initial level of self-confidence may be revised upwards in a successful application episode while it may be revised downwards in an unsuccessful application episode. This research looks at business owners who applied for finance, their financial education and how bank rejection affects self-confidence of SMEs' owners. ${ }^{6}$

[Figure 1 about here]

\section{Sample analysis}

The proportions of overdrafts and commercial loans that are reported in Table 1 are different for 2004 and 2008. The proportions of overall overdrafts and commercial loans rejected in 2004 and 2008 are about $11 \%$ and 16\%, respectively. While overdrafts rejected in 2004 and 2008 are reported as $10.51 \%$ and $15.48 \%$ respectively, loans rejected in 2004 and 2008 are $5.33 \%$ and $9.94 \%$ respectively. The figures show the intensities and negative effects of the recent financial crisis started in 2007 on the financing of SMEs, which are in line with previous research (e.g. McGuinness and Hogan, 2016; Cornett et al., 2011; Popov and Udell, 2012; Ivashina and Scharfstein, 2010).

The proportions of men and women who used overdraft and commercial loans in 2004 and 2008 show gender differences with a greater proportion for men. These variations in overdraft and commercial loan applications among men and women entrepreneurs may be related to varying social and economic factors. According to Bellucci et al. (2010), gender matters in bank-firm relationships because female entrepreneurs experience tighter credit availability. Muravyev et al. (2009) found that female owned businesses in Central and

\footnotetext{
${ }^{6}$ This issue however deserves further empirical investigation, but it requires longitudinal data and methods to study fully the conceptual framework described in Figure 1.
} 
Eastern Europe were less likely to get loans and pay higher interest rates than their male counterparts. To this end, female entrepreneurs may fund their businesses differently and may be dissuaded from obtaining credits in the form of commercial loans and overdrafts. This partially confirms the research of Brindley (2005) as different risk factors are attributed to different gender behaviours. Further research shows that personal characteristics in terms of risk propensity and beliefs can positively impact entrepreneurial intentions (Volery et al., 2013). In addition, GEM (2014) disclosed the cultural and customary explanations for entrepreneurial choices around the world.

In the two samples for this study, the proportion of financially educated is generally less than non-financially educated. The overall proportion of discouraged borrowers in 2004 is $1.80 \%$ and $2.87 \%$ in 2008 . This pattern of discouragement is reflected for both overdraft and commercial loan applications, thus, confirming the increased levels of discouragement among SMEs during the financial crisis of 2007 (e.g. Cornett et al., 2011; Cotugno et al., 2012; McGuinness and Hogan, 2016). The analysis for this study excludes those who did not apply for credit because the business owner thought they would be turned down i.e. discouraged borrowers and those who did not apply because there was no need for finance. Summary statistics of the variables used in this study are provided in the Appendix (Table A1 and Table A2).

[Table 1 about here]

\section{Methodology}

This study used ordered probit estimation techniques (see Wooldridge, 2002) to model owner manager self-confidence in finance, and examine its association with credit rejection rate (RR), financial education (FE) and gender (GE) controlling for individual and firm characteristics (X) (see Wooldridge, 2002). ${ }^{7}$ Entrepreneurs answered the question, "On $a$ scale of 1-10 (where 1 is no confidence and 10 is complete confidence), how confident are you in your own abilities in finance?" Based on the responses, this study constructed a variable that captured self-confidence in finance by taking values from 1 (no confidence) to 10 (complete confidence), assigning the numeric values $\{1 \ldots 10\}$. Since there appeared to be

\footnotetext{
${ }^{7}$ Finally, since we were interested in the information provided in the sample we used un-weighted estimates as unweight regressions can provide consistent and precise estimates (see Longhi and Nandi, 2015: 140-141).
} 
a logical ordering in these responses, the ordered response model was utilized for this study and is presented as $^{8}$ :

$$
S C_{f}^{*}=a_{1} R R_{f}+a_{2} F E_{f}+a_{3} G E+b^{\prime} X_{f}+u_{f}
$$

Where $S C_{f}^{*}$ represent the latent variable denoting the unobserved propensity of entrepreneur $f$ to be self-confident in finance. Although $S C_{f}^{*}$ is unobserved, this study observes $S C_{f}$ such that:

$$
S C_{f}=j \text { if } \gamma_{j-1}<S C_{f}^{*} \leq \gamma_{j}
$$

Where the $a_{i}(i=1,2,3), b$ and $\gamma$ are the parameters to be estimated. $X$ is a row vector of owner manager and business characteristics.

As a way to check 'multicollinearity', this study employed the variance inflation (VIF) and tolerance factors (1/VIF) on the model variables (Gujarati and Porter, 2009, p. 340; Pevalin and Robson, 2009, p. 302). The multicollinearity check for 2004 data showed a Mean VIF of 1.69 and each of the VIF values was between 1.02 and 4.57. In addition, the tolerance values for 2004 data were between 0.982 and 0.219 . However, the multicollinearity for 2008 data showed a Mean VIF of 1.90 and each of the VIF values was between 1.06 and 5.59. The tolerance values for 2008 data were between 0.947 and 0.179 . The results suggested that multicollinearity was not a problem in our study.

\section{Findings}

This study estimated the self-confidence in finance of owner managers in sole proprietor and partnership businesses only because self-confidence in finance data was not available for limited companies. ${ }^{9}$ It first combined the bank finance rejections together and then disaggregated them to examine the differences between outright and partial bank rejections (Table 2). ${ }^{10}$ The results in Table 2 show that whilst outright bank finance rejection reduced

\footnotetext{
${ }^{8}$ This study used probit estimation techniques for robustness check. Hence we constructed a variable capturing self-confidence in finance that took the value of 1 for high reported-self-confidence and 0 otherwise. While high self-confidence in finance is derived from self-confidence levels 6 to 10 (complete confidence) on the likert scale, low self-confidence in finance is from 1 (no confidence) to 5. However, the results were generally similar to those reported from the ordered probit estimator, with a notable exception being that we found some evidence of gender effects. Therefore, we suggest that future survey designs should consider alternative ways of measuring self-confidence in the various aspects of finance

${ }^{9}$ Also, since the sample size for 2008 is relatively small, we re-estimated the model without the inclusion of the business type variable. The omission of this control variable increased the sample size to 308 observations, which is in line with the recommended sample size using the method suggested by Green (1991). However, the results were generally similar, but with an even stronger combined rejection effect.

${ }^{10}$ Previous work (Fraser, 2008) has reported no significant impact of financial self-confidence on the likelihood of bank credit rejection. However, one can argue that shifting self-confidence may imply that the entrepreneur is
} 
the financial self-confidence of owner managers, partial bank finance rejection increased their financial self-confidence in 2004 whereas in 2008 the combined effect was found to be negative and statistically significant. To explain the sign of the partial bank rejection coefficient, it may be viewed as a successful outcome by the applicant. These findings provide partial support for hypothesis 1 suggesting that (outright) bank finance rejection reduces business owners' self-confidence in finance. Moreover, the results in Table 2 show that financial education increases the likelihood of reporting higher financial self-confidence. Thus, our second hypothesis: financial education increases business owners' self-confidence in finance is supported. The overall model finds, however, no association between gender and reported self-confidence in finance and therefore hypothesis 3 is rejected. ${ }^{11}$

[Table 2 about here]

This study further disaggregated the data for overdraft users (Table 3) and for commercial loan users (Table 4). ${ }^{12}$ The models for overdraft users and loan users are interesting. As shown in Table 3, outright overdraft rejection reduces the self-confidence in finance of owner managers in 2004 whereas overall overdraft rejection reduces selfconfidence in finance in 2008. Being financially qualified is still found to increase selfconfidence in finance, and this result is found to be consistent across the estimations. ${ }^{13}$ Similarly, as in the full sample, this study observes no significant differences between males

less capable of correctly assessing his/her entrepreneurial abilities, which is a sign for low human capital and firms with low human capital are more likely to be rejected. In this paper we have experimented by estimating the average treatment effect on the treated (ATT). In particular we allowed the treatment status to be represented by a dummy variable taking the value of 1 if the owner of the firm has experienced bank rejection and 0 otherwise. We then constructed a dummy variable to distinguish between owners with high self-confidence or low-self-confidence (see footnote 1 above) after which we applied propensity matching techniques developed by Becker and Ichino (2002). We estimated the ATT using the nearest neighbour matching algorithm. The results suggest that for firm owners who have experienced a bank rejection, this has caused the probability of having high self-confidence to be $14.2 * *$ (bootstrapped std. err 0.069) and 17.9 (bootstrapped std. err 0.132) percentage points lower than it would have otherwise been for 2004 and 2008 years, respectively. Also, when a probit model is estimated instead the effects are found to be similar in magnitude (reducing the probability by $9.33 * *$ (std. err. 0.054) and 14.86* (std. err. 0.104) percentage points, respectively). Hence, there is some evidence that bank rejection does affect self-confidence in finance.

${ }^{11} \mathrm{We}$ also experimented by interacting the financial qualification variable with the bank rejection variable and also the net worth dummies with the bank rejection variable. Generally we find the interactions to be statistically insignificant with the only exception being the interaction of low net worth (£1-£99,999) which is negative and statistically significant at the $10 \%$ level in the 2004 sample.

12 The results were also similar when the business type variable was omitted from the model to allow for more observations to be available for estimation.

${ }^{13}$ We have tested the hypothesis which states that the coefficients of being financially qualified in the 2004 overdraft users models as shown in Table $2 b$ are equal to the estimated parameters of the loan users models reported in Table $2 c$. The hypothesis, however, cannot be rejected $\left(x^{2}(1)=0.02\right.$ and $x^{2}(1)=0.00$, respectively). 
and females. These models therefore provide further support of hypotheses 1 and 2. For loan user model (Table 4), however, this study finds a positive association between partial bank rejection rate and reported self-confidence in finance. This study also finds some evidence that owner managers with increased self-confidence in finance are more likely to be male than female. This finding provides some support to existing research including Bowen and Hisrich (1986), Estes and Hosseini (1988) and Kirkwood (2009) that women lack adequate self-confidence in financial matters with a negative effect on entrepreneurship. Being financially qualified is also found to have a positive effect, but the effect becomes weak after the crisis. Hence, the latter models provide strong support of hypothesis 3 and some weak support of hypothesis $2 .^{14}$

[Table 3 and 4 about here]

Turning to the control variables, this study also finds some interesting results. For example, VAT registration is found not to be associated with financial self-confidence. This study generally finds neither ethnicity effect on financial self-confidence nor statistically significant firm size effect. Non-start-up is found to be associated with higher financial selfconfidence than new start-ups, especially for overdraft users before crisis. Finally, we find some evidence to suggest that firms with lower net worth are probably less likely to have high levels of financial self-confidence than firms with higher net worth.

\section{Discussion}

The financial self-confidence of owner managers can support their entrepreneurial capabilities in starting and operating one or more businesses. Additionally, this will facilitate and spur economic development as a consequence of job creations and innovation. To this end, this study exposes the importance of financial education on the entrepreneurs' financial self-confidence, and consistent with previous research, we find support for the view that human capital is an advantage for entrepreneurs, society and business success (e.g. OECD, 2006; Unger et al., 2011; Block et al., 2013; Disney and Gathergood, 2013). In particular, this paper finds that financial education increases entrepreneurs' financial self-confidence. It is

\footnotetext{
${ }^{14} \mathrm{We}$ also run estimates for both males and females sub-samples (results are available upon request). The results show that bank credit rejection affects the financial self-confidence of males during the crisis and women before the crisis. Additionally, we find that financial qualification boosts self-confidence of females during the crisis whereas for males it has a positive effect before the crisis started. Overall, these gender specific results provide further support of both hypothesis 1 and 2 .
} 
argued that financial literacy and knowledge can help entrepreneurs in providing relevant and coherent information to banks and other lenders, which in turn improves the entrepreneurs' lending relationship with their banks and related outcomes. Hence, the government should encourage policy support to enable financial education and training for potential entrepreneurs (especially those currently unemployed) towards boosting their financial selfconfidence and improving their zeal for entrepreneurship. Additionally, entrepreneurs and potential entrepreneurs are encouraged to explore financial literacy with a view to increasing their financial self-confidence. However, seeking financial advice or financial counselling externally may serve as an alternative to owner manager pursuing financial education, but this is subject to a strategic decision by the firm as there may be cost implications.

Additionally, it is found that bank credit rejection experiences, in the form of outright rejections, reduce the entrepreneurs' financial self-confidence. This raises a number of issues for financial institutions, professional bodies and entrepreneurs. Firstly, the application process should involve advice from financial experts such as accountants who can help with the preparation of the funding application as well as explain lending criteria information, especially to naïve borrowers. Secondly, professional bodies should consider ways of overcoming the barriers associated with SMEs seeking assistance in applying for funding. This involves issues related to pricing in accountancies and legal services, knowledge of the services that are available and trust between the SME owners and the external advisors. Thirdly, the government should provide and promote schemes that inform entrepreneurs about how credit decisions are made, how to prepare a business plan, and advice on the amount of finances that are required. This can be done in a close collaboration with professional bodies that will ensure that SMEs receive the necessary support and information when applying for funding. These measures may reduce the risks of bank credit rejections for their business ventures and generally improve bank lending.

\section{Conclusion and future directions}

This paper examined empirically the link between self-confidence in finance, bank finance rejection rates, gender and financial education using the 2004 and 2008 SME finance surveys. The results showed that outright bank credit rejection is negatively associated with financial self-confidence, whereas partial bank credit rejection may boost self-confidence. Moreover, the results showed that financial education has a strong and positive effect on self-confidence in finance. Thus, our results support the need for increasing entrepreneurial and financial education in higher education. 
This research, however, has few limitations. Firstly, the SME finance data for 2004 and 2008 is based on UK firms. Therefore, the results may be generalizable only to SMEs in the UK and, other similarly developed countries. As such there must be caution in applying the results in a worldwide context as institutions, for instance, are not homogeneous. Secondly, the research is based on cross-sectional data. Although both year periods provided the opportunity for comparative analysis in this research, it does not replace the capability of longitudinal panel data. Thus, panel data could have supported greater analytical depth and details of the differences in reported financial self-confidence and variations in bank credit rejection rates. Thirdly, the SME finance survey captured financial self-confidence data for sole proprietor and partnership businesses only. Therefore, it was not possible to examine empirically other legal forms of firms. Hence, further research is recommended to evaluate and assess the financial self-confidence of owner managers in limited companies, social enterprises and charities to determine their bank credit rejection rate and their gender aspect. This knowledge will allow owner managers to resolve their deficiencies in financial education as a way to increase their self-confidence in finance and facilitate their readiness for entrepreneurship. Financial education could be one suitable way to increase selfconfidence in finance and improve entrepreneurship. Hence, different types of firms have the potential to benefit from the financial self-confidence of the owner or leader. 


\section{References}

Abildgren, K., Drejer, P. A. and Kuchler, A. (2013), "Banks' loan rejection rates and the creditworthiness of the banks' corporate customers", available at: https://www.djoefforlag.dk/sites/nt/files/2013/2013_8.pdf (accessed 19 December 2015).

Alsos, G. A., Isaksen, E. J. and Ljunggren, E. (2006), "New venture financing and subsequent business growth in men - and women-led businesses", Entrepreneurship Theory and Practice, Vol. 30 No. 5, pp. 667-686.

Amatucci, F. M. and Crawley, D. C. (2011), "Financial self-efficacy among women entrepreneurs", International Journal of Gender and Entrepreneurship, Vol. 3 No. 1, pp. 2337.

Asoni, A (2011), Intelligence, "Self-confidence and Entrepreneurship", IFN Working Paper No. 887, 2011. Available at http://www.ifn.se/wfiles/wp/wp887.pdf

Bandura, A. (1982). "Self-Efficacy Mechanism in Human Agency". American Psychologist, $37,122-147$.

Bandura, A. (1994). "Self-efficacy". In V. S. Ramachaudran (Ed.), Encyclopedia of human behaviour (pp. 71-81). New York: Academic Press.

Barber, B. M. and Odean, T. (2001), "Boys will be boys: Gender, overconfidence, and common stock investment", The Quarterly Journal of Economics, Vol. 116 No. 1, pp. 261292.

Bass, B.M. (1990). “Stogdill’s handbook of leadership”. New York: Free Press.

Becker, S.O. and Ichino, A. (2002), "Estimation of average treatment effects based on propensity scores", Stata Journal, 2(4), 358-377.

Bellucci, A., Borisov, A. and Zazzaro, A. (2010), "Does gender matter in a bank-firm relationships?", Journal of Banking \& Finance, Vol. 34 No. 12, pp. 2968-2984.

Berger, A. N., Espinosa-Vega, M. A., Frame, W. S. and Miller, N. H. (2011), "Why do borrowers pledge collateral? New empirical evidence on the role of asymmetric information", Journal of Financial Intermediation, Vol. 20 No. 1, pp. 55-70.

Bester, H. (1987), "The role of collateral in credit markets with imperfect information", European Economic Review, Vol. 31 No. 4, pp. 887-899.

Berg, G. and Kirschenmann, K. (2012). "Funding vs. real economy shock: the impact of the 2007- 2009 crisis on small firms' credit availability”. World Bank Policy Research Working Paper, (6030)

BIS (2012), "SME access to external finance", BIS Economics Paper No. 16, available at: https://www.gov.uk/government/uploads/system/uploads/attachment_data/file/32263/12-539sme-access-external-finance.pdf (accessed 22 May 2015). 
Block, J. H., Hoogerheide, L. and Thurik, R. (2013), "Education and entrepreneurial choice: An instrumental variables analysis", International Small Business Journal, Vol. 31 No. 1, pp. 23-33.

Blumberg B.F, (2007), "Business starters and credit rationing." Small Business Economics, Vol. 30, No.2), pp.187-200.

Blundell, R., Dearden, L., Meghir, C. and Sianesi, B. (1999), "Human capital investment: The returns from education and training to the individual, the firm and the economy", Fiscal Studies, Vol. 20 No. 1, pp. 1-23.

Bowen, D. D. and Hisrich, R. D. (1986), “The female entrepreneur: A career development perspective", Academy of Management Review, Vol. 11 No. 2, pp. 393-407.

Brindley, C. (2005), "Barriers to women achieving their entrepreneurial potential: Women and risk", International Journal of Entrepreneurial Behaviour \& Research, Vol. 11 No. 2, pp. 144-161.

Busenitz, L., and Barney, J. (1997), "Differences between entrepreneurs and managers in large organizations: Biases and heuristics in strategic decision-making," Journal of Business Venturing, Vol.12, pp.9-30.

Caleb, K, Dylan. J, and Piers, T, (2012), "Differences in perceptions of access to finance between potential male and female entrepreneurs: Evidence from the UK", International Journal of Entrepreneurial Behavior \& Research, Vol. 18, No.1, pp.75 - 97

Carbó-Valverde, S., Rodriguez-Fernandez, F. and Udell, G. F. (2013), "Trade credit, the financial 98 crisis, and SME access to finance". In 26th Australasian Finance and Banking Conference.

Cho, Y. and Honorati, M. (2013), "Entrepreneurship programmes in developing countries: A Meta regression analysis", IZA Discussion Paper no. 7333, available at: http://ftp.iza.org/dp7333.pdf (accessed 30 November 2015).

Cole, R. and Sokolyk, T. (2016), "Who needs credit and who gets credit? Evidence from the surveys of small business finance", Journal of Financial Stability, Vol. 24, pp. 40-60.

Colombo, M. G. and Grilli, L. (2005), "Founders' human capital and the growth of new technology-based firms: A competence-based view", Research Policy, Vol. 34 No. 6, pp. 795-816.

Cornett, M. M., McNutt, J. J., Strahan, P. E. and Tehranian, H. (2011), "Liquidity risk management and credit supply in the financial crisis", Journal of Financial Economics, Vol. 101 No. 2, pp. 297-312.

Cotugno, M., Monferrà, S. and Sampagnaro, G. (2012), "Relationship lending, hierarchical distance and credit tightening: Evidence from the financial crisis", Journal of Banking \& Finance, Vol. 37 No. 5, pp. 1372-1385. 
Cowling, M., Liu, W., Minniti, M. and Zhang, N. (2016), "UK credit and discouragement during the GFC”, Small Business Economics, Vol. 47 No. 4, pp. 1049-1074.

Crook, T. R., Todd, S. Y., Combs, J. G., Woehr, D. J. and Ketchen, D. J. (2011), "Does human capital matter? A meta-analysis of the relationship between human capital and firm performance", Journal of Applied Psychology, Vol. 96 No. 3, pp. 443-456.

Dakhli, M. and De Clercq, D. (2004), "Human capital, social capital, and innovation: multicountry study", Entrepreneurship \& Regional Development: An International Journal, Vol. 16 No. 2, pp. 107-128.

del-Palacio I, Zhang X and Sole F (2010), "The capital gap for small technology companies: Public venture capital to the rescue?", Small Business Economics. Epub ahead of print, 16 April 2010.

Deyoung, R., Gron, A., Torna, G., and Winton, A. (2015), "Risk Overhang and Loan Portfolio Decisions: Small Business Loan Supply before and during the Financial Crisis: Risk Overhang and Loan Portfolio Decisions," The Journal of Finance, Vol.70, No.6, pp. 24512488.

Dickson, P. H., Solomon, G. T. and Weaver, K. (2008), "Entrepreneurial selection and success: Does education matter?" Journal of Small Business and Enterprise Development, Vol. 15 No. 2, pp. 239-258.

Disney, R. and Gathergood, J. (2013), "Financial literacy and consumer credit portfolios", Journal of Banking \& Finance, Vol. 37 No. 7, pp. 2246-2254.

Drexler, A., Fischer, G. and Schoar, A. (2013), "Keeping it simple: Financial literacy and rules of thumb", available at: http://www.mit.edu/ aschoar/KIS-DFS-March2013.pdf (accessed 30 November 2015).

ECB Monthly Bulletin (2014), "SME access to finance in the Euro area: Barriers and potential policy remedies", available at: https://www.ecb.europa.eu/pub/pdf/other/art2_mb201407_pp79-97en.pdf (accessed 22 November 2015).

Estes, R. and Hosseini, J. (1988), "The gender gap on Wall Street: An empirical analysis of confidence in investment decision making", The Journal of Psychology, Vol. 122 No. 6, pp. 577-590.

Fernandes, D., Lynch Jr, J. G. and Netemeyer, R. G. (2014), "Financial literacy, financial education and downstream financial behaviours", available at: http://papers.ssrn.com/sol3/papers.cfm?abstract_id=2333898 (accessed 30 November 2015).

Forbes Insights (2010), "Small and Medium Sized Enterprises: Rebuilding a foundation for post-recovery growth", available at:

http://images.forbes.com/forbesinsights/StudyPDFs/SME_RebuildingAFoundation.pdf (accessed 30 November 2015). 
Fraser, S. (2004), "United Kingdom Survey of Small- and Medium-Sized Enterprises' Finances", Doi: 10.5255/UKDA-SN-5326-1, UK Data Archive, Colchester, UK.

Fraser, S. (2008), "United Kingdom Survey of Small- and Medium-Sized Enterprises' Finances", Doi: 10.5255/UKDA-SN-6314-1, UK Data Archive, Colchester, UK.

Galasso, A. and Simcoe, T, (2010), "CEO Overconfidence and Innovation", Management Science, Vol.57 No.3, pp 1469-1484.

Ganotakis, P. (2012), "Founders' human capital and the performance of UK new technology based firms”, Small Business Economics, Vol. 39 No. 2, pp. 495-515.

GEM (2014), "Global entrepreneurship monitor 2013 global report", available at: http://www.gemconsortium.org/report (accessed 04 November 2015).

Green, S.B. (1991), "How many subjects does it take to do a regression analysis", Multivariate Behavioral Research, 26(3), 499-510.

Gujarati, D. N. and Porter, D. C. (2009), "Basic econometrics", McGraw-Hill International, New York, NY.

Gupta, V. K., Goktan, A. B. and Gunay, G. (2014), "Gender differences in evaluation of new business opportunity: A stereotype threat perspective", Journal of Business Venturing, Vol. 29 No. 2, pp. 273-288.

Gurnani. S.P., (2014)," Study of Financial Problems of Women Entrepreneurs," Global Journal of Finance and Management, Vol. 6, No. 3, pp. 223-226

Hayward, M., Forster, W., Sarasvathy, S., Fredrickson, B., (2010). "Beyond hubris: How highly confident entrepreneurs rebound to venture again," Journal of Business Venturing, Vol.25, pp. 569-578.

Heunks, F. J. (1998). "Innovation, creativity, and success". Small Business Economics, Vol.10 No. 3, pp. 263-272.

Huang, J. and Kisgen, D. J. (2013), "Gender and corporate finance: Are male executives overconfident relative to female executives?" Journal of Financial Economics, Vol. 108 No. 3, pp. 822-839.

Ivashina, V. and Scharfstein, D. (2010), "Bank lending during the financial crisis of 2008", Journal of Financial Economics, Vol. 97 No.3, pp. 319-338.

Jones, K. and Tullous, R. (2002), "Behaviors of pre-venture entrepreneurs and perceptions of their financial needs", Journal of Small Business Management, Vol. 40 No. 3, pp. 233-248.

Karlan, D. and Valdivia, M. (2010), "Teaching entrepreneurship: Impact of business training on microfinance clients and institutions", Review of Economics and Statistics, Vol. 93 No. 2, pp. 510-27. 
Kirkwood, J. (2009), "Is a lack of self-confidence hindering women entrepreneurs?" International Journal of Gender and Entrepreneurship, Vol. 1 No. 2, pp. 118-133.

Koellinger, P., Minniti M., and Schade C. (2007), "I Think I Can, I Think I Can": Overconfidence and Entrepreneurial Behavior," Journal of Economic Psychology, Vol.28, pp. 502-527.

Kremp, E., and Sevestre, P. (2013), "Did the crisis induce credit rationing for French SMEs?" Journal of Banking \& Finance,Vol. 37, No.10, pp. 3757-3772.

Lee, N., Sameen, H. and Cowling, M. (2015), "Access to finance for innovative SMEs since the financial crisis", Research Policy, Vol. 44 No. 2, pp. 370-380.

Longhi, S. and Nandi, A. (2015), “A practical guide to using panel data”, Sage Publishing.

Malmendier, U. and G. Tate (2008), "Who makes acquisitions? CEO overconfidence and the market's reaction”. Journal of Financial Economics Vol.89 No.1, pp. 20-43.

Marlino, D. and Wilson, F (2003), "Teen girls on business: Are they being empowered?" Boston and Chicago: Simmons School of Management and The Committee of 200.

McGee, J.E., Peterson, M. and Mueller, S.L. (2009), "Entrepreneurial self-efficacy: refining the measure", Entrepreneurship Theory and Practice, Vol. 33 No. 4, pp. 965-88.

McGuinness, G. and Hogan, T. (2016), "Bank credit and trade credit: Evidence from SMEs over the financial crisis", International Small Business Journal, Vol. 34 No. 4, pp. 412-445.

Meenakshi and Mahapatra, S.N., (2015), "Constraints faced by women entrepreneurs", Journal Impact Factor, Vol.6, No.5, pp. 08-17. Minniti, M., Arenius, P. and Langowitz, N. (2004), "Global Entrepreneurship Monitor: 2004 Report on Women and Entrepreneurship", The Center for Women's Leadership at Babson College, Babson Park, MA.

Minniti, M., Arenius, P. and Langowitz, N. (2004), Report on Women and Entrepreneurship, Global Entrepreneurship Monitor, Babson College and London Business School

Möbius, M. M., Niederle, M., Niehaus, P. and Rosenblat, T. S. (2011), "Managing selfconfidence: Theory and experimental evidence”, NBER Working Paper No. 17014.

Moore, D. A. and Healy, P. J. (2008), "The trouble with overconfidence", Psychological Review, Vol. 115 No. 2, pp. 502-517.

Muravyev, A., Talavera, O. and Schäfer, D. (2009), "Entrepreneurs' gender and financial constraints: Evidence from International data", Journal of Comparative Economics, Vol. 37 No. 2, pp. 270-286.

OECD (2006), "The importance of financial education", available at: http://www.oecd.org/finance/financial-education/37087833.pdf__accessed 15 December 2015). 
OECD (2013), "Financing small business: a key to economic recovery", available at: http://www.oecd.org/cfe/smes/financing-small-business-key-to-economic-recovery.htm (accessed 21 December 2015).

Parker, S.C. (2006), "Learning about the unknown: how fast do entrepreneurs adjust their beliefs?" Journal of Business Venturing, Vol. 21, pp. 1-26.

Pevalin, D., \& Robson, K. (2009). The Stata survival manual. New York, NY: McGrawHill.

Pirinsky, C. (2013), "Confidence and economic attitudes", Journal of Economic Behavior \& Organization, Vol. 91 pp. 139-158.

Popov, A. and Udell, G. F. (2012), "Cross-border banking, credit access, and the financial crisis”, Journal of International Economics, Vol. 87 No. 1, pp. 147-151.

Rae, D. and Carswell, M. (2001), "Towards a conceptual understanding of entrepreneurial learning”, Journal of Small Business and Enterprise Development, Vol. 8 No. 2, pp. 150-158.

Revathi, S and Krishnan, J, (2012), "Analysis Of Problems And Prospects Of Women Entrepreneurs In Their Development", South Asian Journal of Marketing \& Management Research, Vol 2, No. 6 (June, 2012).

Robinson, M. S. (2001), "The microfinance revolution: Sustainable finance for the poor", IBRD/The World Bank Publications, Washington DC.

Saridakis, G., Marlow, S. and Storey, D. J. (2014), "Do different factors explain male and female self-employment rates?” Journal of Business Venturing, Vol. 29 No. 3, pp. 345-362.

Saridakis, G., Mole, K. and Storey, D. J. (2008), "New small firm survival in England", Empirica, Vol. 35 No. 1, pp. 25-39.

Scottish Government (2014) Report on SME access to finance. Available at: http://www.gov.scot/Resource/0047/00474061.pdf (accessed 01 May 2016).

Shepherd, D., Douglas, E., Shanley, M., (2010). "New venture survival: Ignorance, external shocks and risk reduction strategies," Journal of Business Venturing, Vol.15, pp. 393-410.

Smallbone, D., Deakins, D., Battisti, M. and Kitching, J. (2012), "Small business responses to a major economic downturn: Empirical perspectives from New Zealand and the United Kingdom", International Small Business Journal, Vol. 30 No. 7, pp. 754-777.

Trevelyan, R. (2008), "Optimism, overconfidence and entrepreneurial activity", Management Decision, Vol. 46 No. 7, pp. 986-1001.

Tyszka, T., Cieślik, L., Domurat, A. and Macko, A. (2011), "Motivation, self-efficacy, and risk attitudes among entrepreneurs during transitions to a market economy", Journal of Socio-Economics, Vol. 40 No. 2, pp. 124-131.

Ucbasaran, D., Westhead, P. and Wright, M. (20015) "Habitual Entrepreneurs Experiencing Failure: Overconfidence and the Motivation to Try Again” In Entrepreneurship: Frameworks And Empirical Investigations From Forthcoming Leaders Of European Research. 
Unger, J. M., Rauch, A., Frese, M. and Rosenbusch, N. (2011), "Human capital and entrepreneurial success: a meta-analytical review", Journal of Business Venturing, Vol. 26 No. 3, pp. 341-358.

Volery, T., Muller, S., Oser, F., Naepflin, C. and del Rey, N. (2013), "The impact of entrepreneurship education on human capital at upper-secondary level", Journal of Small Business Management, Vol. 51 No. 3, pp. 429-446.

Voordeckers, W. and Steijvers, T. (2006), "Business collateral and personal commitments in SME lending", Journal of Banking \& Finance, Vol. 30 No. 11, pp. 3067-3086.

Wijewardena, H., Nanayakkara, G. and De Zoysa, A. (2008), "The owner/manager's mentality and the financial performance of SMEs", Journal of Small Business and Enterprise Development, Vol. 15 No. 1, pp. 150-161.

Wooldridge, J. (2002), “Econometric Analysis of Cross Section and Panel Data”, MIT Press.

Yazdipour, Rassoul and Richard Constand (2010). "Predicting Firm Failure: A Behavioral Finance Perspective" The Journal of Entrepreneurial Finance, Vol. 14, Iss. 3, pp. 90-104. 
Figure 1: Conceptual framework of self-confidence and credit finance application

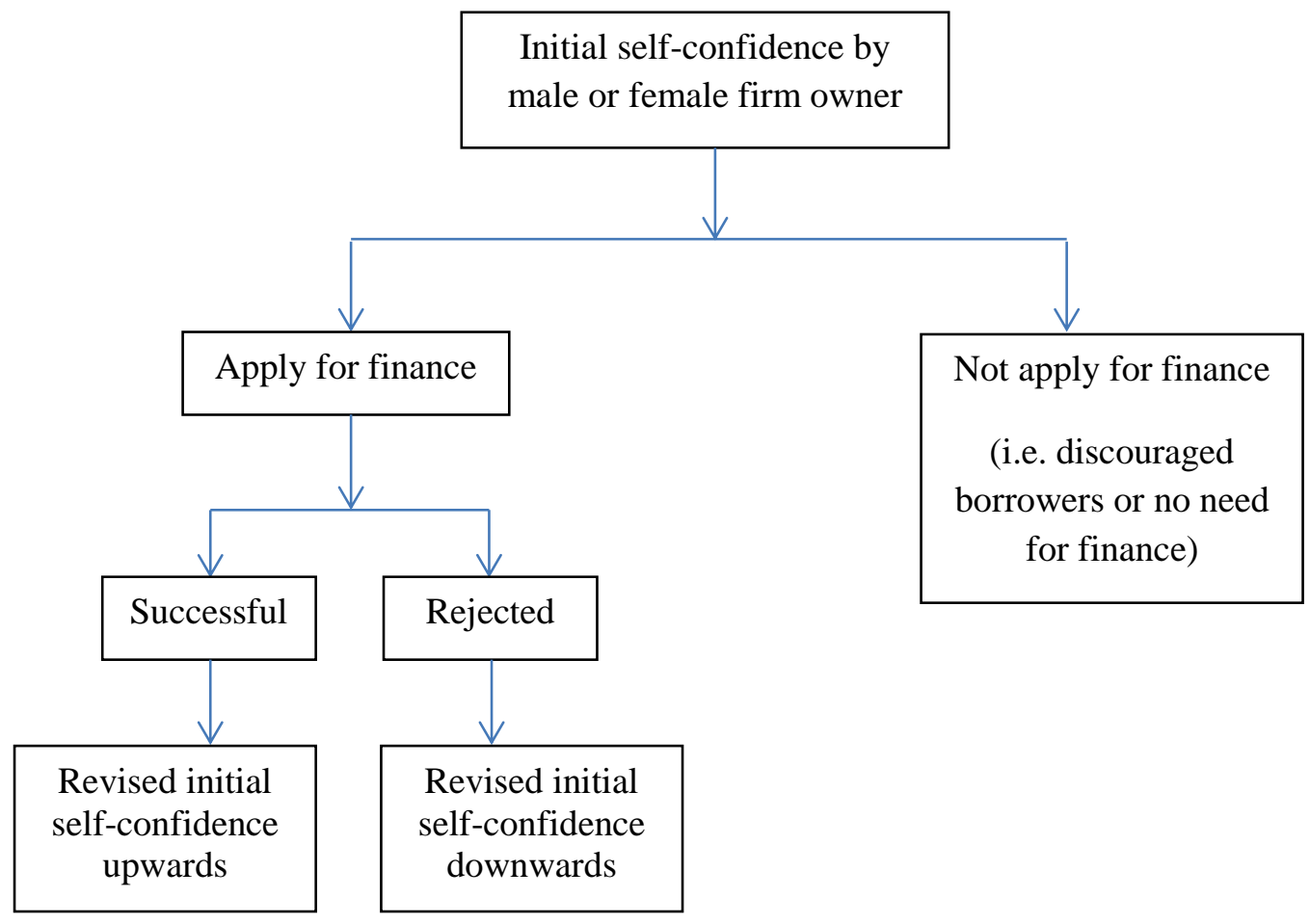


Table 1: Sample properties (\%)

\begin{tabular}{lccc|ccc}
\hline & \multicolumn{3}{c|}{2004} & \multicolumn{3}{c}{2008} \\
\cline { 2 - 7 } Properties & Overall & Overdraft & Loan & Overall & Overdraft & Loan \\
\hline Rejected & 11.34 & 10.51 & 5.33 & 16.43 & 15.48 & 9.94 \\
Men & 80.80 & 80.93 & 82.76 & 80.41 & 80.32 & 81.99 \\
Financial education & 20.77 & 21.98 & 24.76 & 21.05 & 21.61 & 21.12 \\
$N$ & 573 & 514 & 319 & 342 & 310 & 161 \\
\hline & & & & & & \\
Discouraged borrowers & 1.80 & 3.66 & 2.04 & 2.87 & 3.94 & 3.71 \\
$N$ & 500 & 246 & 441 & 383 & 203 & 350 \\
\hline & & & & & & \\
Finance is needed & 6.72 & 5.91 & 4.86 & 5.91 & 4.10 & 5.34 \\
$N$ & 491 & 237 & 432 & 372 & 195 & 337 \\
\hline
\end{tabular}

Note: The sample size $(N)$ for 2004 data is greater than 2008 . 
Table 2: Ordered probit of self-confidence in finance

\begin{tabular}{|c|c|c|c|c|}
\hline \multirow{2}{*}{$\begin{array}{l}\text { Independent variables } \\
\text { Applied (base category: Successful) }\end{array}$} & \multicolumn{2}{|c|}{2004} & \multicolumn{2}{|c|}{2008} \\
\hline & & & & \\
\hline - Bank finance rejection & $-0.0462(0.1496)$ & & $-0.4363(0.2432)^{*}$ & \\
\hline - Partial bank finance rejection & & $0.3215(0.1811)^{*}$ & & $-0.1130(0.3053)$ \\
\hline - Outright bank finance rejection & & $-0.4189(0.2212)^{*}$ & & $-0.2817(0.3273)$ \\
\hline Gender (base category: Female) & & & & \\
\hline - Male & $0.1069(0.1193)$ & $0.0920(0.1196)$ & $0.0523(0.2145)$ & $0.0265(0.2178)$ \\
\hline Business type (base category: Start-up) & & & & \\
\hline - Non start-up & $0.1845(0.2101)$ & $0.1597(0.2101)$ & $0.0269(0.2784)$ & $0.0052(0.2798)$ \\
\hline - Degree qualified & $0.0067(0.1183)$ & $0.0122(0.1184)$ & $-0.2954(0.2249)$ & $-0.2925(0.2271)$ \\
\hline Financial education (base category: no financial qualification) & & & & \\
\hline $\begin{array}{l}\text { - Financially qualified } \\
\text { Firm size (base category: medium sized firms) }\end{array}$ & $0.3401(0.1191)^{* * *}$ & $0.3336(0.1192)^{* * *}$ & $0.6606(0.2679)^{* *}$ & $0.6795(0.2680) * *$ \\
\hline - Micro firm & $-0.1755(0.1978)$ & $-0.1773(0.1978)$ & $-0.0215(0.4547)$ & $0.0005(0.4542)$ \\
\hline - Small firm & $-0.0239(0.1966)$ & $-0.0193(0.1967)$ & $-0.2800(0.4480)$ & $-0.2782(0.4478)$ \\
\hline VAT registration (base category: no VAT registered) & & & & \\
\hline - VAT registered firm & $-0.0824(0.1063)$ & $-0.0924(0.1064)$ & $0.2044(0.2017)$ & $0.2021(0.2052)$ \\
\hline Ethnicity (base category: non-white British) & & & & \\
\hline Firm net worth (base category: net worth above £999,999) & & & & \\
\hline - Net worth $£ 1$ to $£ 99,999$ & $-0.2339(0.1472)$ & $-0.2245(0.1474)$ & $-0.4013(0.2773)$ & $-0.4112(0.2780)$ \\
\hline - Net worth $£ 100,000$ to $£ 499,999$ & $-0.0781(0.1193)$ & $-0.0938(0.1195)$ & $-0.0230(0.2472)$ & $-0.0302(0.2476)$ \\
\hline - Net worth $£ 500,000$ to $£ 999,999$ & $0.0253(0.1528)$ & $0.0130(0.1530)$ & $0.3009(0.3543)$ & $0.2807(0.3544)$ \\
\hline Log likelihood & -975.2305 & -972.5280 & -234.1324 & -235.0939 \\
\hline LR Chi2(12)(13) & 22.96 & 28.36 & 20.23 & 18.30 \\
\hline Prob $>$ Chi2 & 0.0281 & 0.0080 & 0.0629 & 0.1463 \\
\hline Observation & 546 & 546 & 133 & 133 \\
\hline
\end{tabular}

Note: Standard errors are shown in parentheses. Significance: $* * * p<0.01 * * \mathrm{p}<0.05 * \mathrm{p}<0.10$. Estimates are shown in coefficients. 
Table 3: Ordered probit of self-confidence in finance for overdraft users

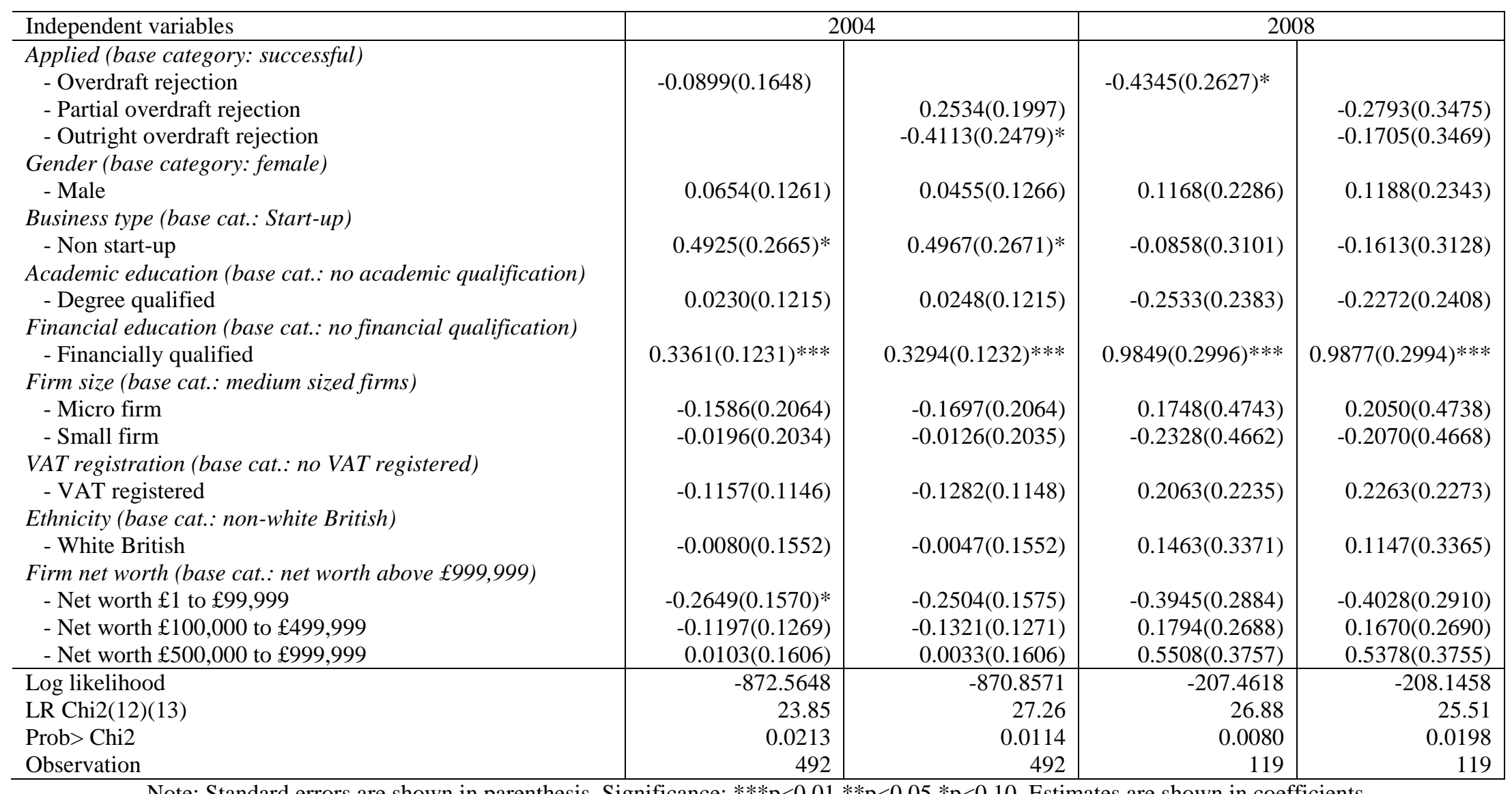

Note: Standard errors are shown in parenthesis. Significance: $* * * \mathrm{p}<0.01 * * \mathrm{p}<0.05 * \mathrm{p}<0.10$. Estimates are shown in coefficients. 
Table 4: Ordered probit of self-confidence in finance for loan users

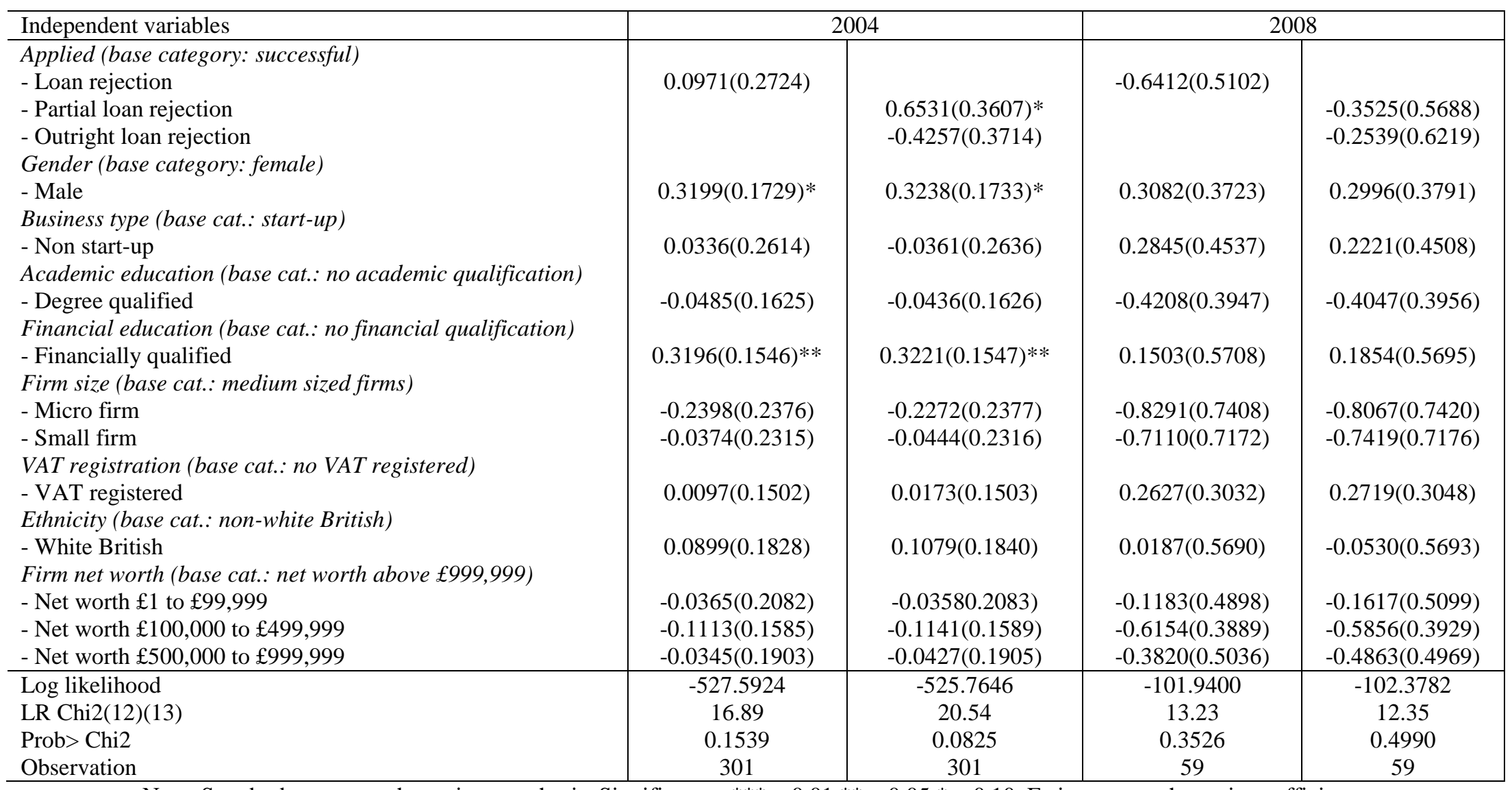

Note: Standard errors are shown in parenthesis. Significance: $* * * \mathrm{p}<0.01 * * \mathrm{p}<0.05 * \mathrm{p}<0.10$. Estimates are shown in coefficients. 


\section{Appendix}

Table A1: Summary list of dependent and explanatory variables for 2004

\begin{tabular}{l|ccc}
\hline Variable & Mean & Min & Max \\
\hline Self-confidence & 7.9474 & 1 & 10 \\
Business start-up & 0.0671 & 0 & 1 \\
Degree qualified & 0.1842 & 0 & 1 \\
Financially qualified & 0.2000 & 0 & 1 \\
Gender & 0.7908 & 0 & 1 \\
Outright overdraft reject & 0.0506 & 0 & 1 \\
Partial overdraft reject & 0.0720 & 0 & 1 \\
Outright loan reject & 0.0313 & 0 & 1 \\
Partial loan reject & 0.0345 & 0 & 1 \\
VAT registered & 0.6618 & 0 & 1 \\
Ethnicity - White British & 0.9026 & 0 & 1 \\
Net worth -1 to 99,999 & 0.1931 & 0 & 1 \\
Net worth $-100,000$ to 499,999 & 0.4317 & 0 & 1 \\
Net worth $-500,000$ to 999,999 & 0.1338 & 0 & 1 \\
Micro business & 0.6921 & 0 & 1 \\
Small business & 0.2553 & 0 & 1 \\
\hline Altough no repoded
\end{tabular}

Although not reported here, for the 2004 data, we find that there are no differences in the means between males and females with the sole exception being the mean VAT registered. Comparing those not applying for funding we find that there are statistically significant differences (at 5\% significance level) between discouraged and non-discouraged borrowers in terms firm size and ethnicity. However no significant difference is found between those in financial need and those who are not. 
Table A2: Summary list of dependent and explanatory variables for 2008

\begin{tabular}{l|ccc}
\hline Variable & Mean & Min & Max \\
\hline Self-confidence & 7.8472 & 1 & 10 \\
Business start-up & 0.1872 & 0 & 1 \\
Degree qualified & 0.2689 & 0 & 1 \\
Financially qualified & 0.2143 & 0 & 1 \\
Gender & 0.7956 & 0 & 1 \\
Outright overdraft reject & 0.1019 & 0 & 1 \\
Partial overdraft reject & 0.0860 & 0 & 1 \\
Outright loan reject & 0.0539 & 0 & 1 \\
Partial loan reject & 0.0599 & 0 & 1 \\
VAT registered & 0.5977 & 0 & 1 \\
Ethnicity - White British & 0.8182 & 0 & 1 \\
Net worth -1 to 99,999 & 0.1970 & 0 & 1 \\
Net worth $-100,000$ to 499,999 & 0.3771 & 0 & 1 \\
Net worth $-500,000$ to 999,999 & 0.1186 & 0 & 1 \\
Micro business & 0.7326 & 0 & 1 \\
Small business & 0.2267 & 0 & 1 \\
\hline Alt
\end{tabular}

Although it is not reported here, for the 2008 data, we find significant differences (at the 5\% significance level) in the means of financial qualification and VAT registered variables when comparing males and females. For those who are not applying for funding, we find mean differences in ethnicity, net worth and firm size between discouraged borrowers and non-discouraged borrowers. Also, the means of VAT registered and net worth are found to differ between those in financial need and those who are not. 